\title{
"We're Going to Nicaragua": The United States, Nicaragua, and Counterterrorism in Central America during the 1980s
}

\section{by Philip Travis}

\section{(cc) $\mathrm{EY}$}

This work is licensed under a Creative Commons Attribution 3.0 License.

\section{Abstract}

During the first two years of Ronald Reagan's second term the United States developed an offensive strategy for dealing with conflict in the developing world. States like Nicaragua were the prime target of this policy. Scholars refer to this as the Reagan offensive: the first time that the United States eschewed the norms of containment and sought to "roll-back" the gains of communism. However, the Reagan offensive was also significantly driven by a response to the emergent threat of international terrorism. U.S. policy with Nicaragua demonstrates the importance of terrorism in the development of a more aggressive United States.

$]$ n 1989, ten years after the Sandinista revolution in Nicaragua, Orion Pictures produced a film titled "Speedzone." This motion picture was the third in a trilogy of comedies made about the illegal crosscountry motor race, “The Cannon Ball Run.” The movie featured a collection of significant American personalities that included John Candy, Brooke Shields, Carl Lewis, and the Smothers Brothers. In one of the later scenes, the Smothers Brothers, playing themselves, bought plane tickets in an attempt to cheat in the race by flying, rather than driving, from Las Vegas to Los Angeles. The flight attendant on the plane was the darling of the 1980s, Brooke Shields. Shields joked about the lowly quality of her airline. Then, suddenly, a dark skinned man jumped up, drew two guns and shouted "this is a hijack, we're going to Nicaragua!" Shields and the pilots struggled with the Nicaraguan terrorist and Brooke knocked the villain out with a food service tray. The reason this is interesting is because no Nicaraguan conducted a major airline hijack during the 1980s. Nor were there any other types of international terrorist acts that the Sandinistas directly perpetrated. So, why does this popular image of a Nicaraguan international terrorist exist? The answer to this question rests at the heart of this article.[1]

Between 1983 and 1985 a succession of international terrorist acts caused a change in U.S. Cold War policy. One of the most urgent moments came in June 1985. That month gunmen shot and killed six U.S. citizens in San Salvador, El Salvador. Among the dead were 4 off-duty Marines. Days before, militants hijacked TWA 847 in one of the most visible and controversial hijackings of the period. The hijackers sought a prisoner exchange with Israel and took the plane to Beirut, Lebanon, where for days the militants made demands through western media outlets. The events were a capstone to an escalation of terrorist incidents throughout the world.[2] The front page of the New York Times on June 21 covered three different terrorist incidents, the El Salvador killings, the TWA hijacking, and a deadly bombing at the airport in Frankfurt, Germany.[3] The events provided a catalyst for the development of a United States counterterrorism offensive against state sponsors of terrorism.

The period from 1984 to 1986 was one of significant change for U.S. policy with Central America and also the wider world. The transformation carried two thrusts often referred to by scholars as the Reagan doctrine and the Reagan offensive. The Reagan doctrine declared that the United States intended to actively pursue 


\section{Journal of Terrorism Research}

democratic change in the world. For Sandinista-led Nicaragua, a government already facing U.S. military pressure and that the Reagan administration insisted was the anti-thesis of democracy, this amounted to an open assertion that the United States' goal was regime change. The Sandinista government was a primary target of the Reagan doctrine. The Reagan offensive facilitated this policy primarily through the use of proxy armies trained by the Central Intelligence Agency (CIA) and other U.S. advisors. For the Reagan administration, irregular armies like the Nicaraguan Contras held the front lines in a war to make Central America 'safe for democracy.'

From the late 1980s until the early 2000s several excellent scholars documented U.S.-Nicaragua relations during the Reagan administration. Scholars interpreted this history from economic, ideological, and political perspectives. William LeoGrande, Cynthia Arnson, Greg Grandin, Robert Kagan and Walter LaFeber provided some of the most significant scholarship of this period. LaFeber, the ground-breaking revisionist scholar, argued that the anti-U.S. revolutions in Central America resulted from a long history of economic imperialism. In his still relevant 1980s publication, LaFeber argued that these conflicts represented "inevitable revolutions" brought about by a century of U.S. economic exploitation. Kagan provided the most in-depth interpretation of the conflict between the United States and Nicaragua. His monograph, $A$ Twilight Struggle, was a roughly 900 page meta-narrative that missed no detail about this period in U.S.Nicaraguan relations. However, Kagan's point of view as a Reagan insider resulted in an overly defensive narrative. LeoGrande, Arnson, and Grandin, however, criticized the Reagan administration's guerrilla war. Most recently, Greg Grandin emphasized the importance of neo-conservative ideology as the justification for a U.S.-led terror war in Central America. Grandin insisted that the goal of neoconservatives to remake the world in the capitalist-democratic model drove the Reagan offensive in Central America.[4]

As impressive as the scholarship is, most of the best works are 10 to 20 years old. The release of formerly classified documents over the past 10 years allows for a reappraisal that demonstrates the importance of terrorism to the development of the Reagan offensive in Nicaragua. For the most part, scholars ignore the counterterrorism component of this story. Several historians, political scientists, and journalists have considered the Reagan administration's late-Cold War handling of the issue of terrorism, but these scholars tend to focus on the Middle East and the Mediterranean. Typically, Central America is overlooked as a brief side note or is written off as not relevant to the counterterrorism discussion.[5] Even David C. Wills, author of an impressive work on the Reagan administration's counterterrorism policy, pays little attention to the relevance of counterterrorism to the United States' proxy war in Central America. [6] This article is drawn from a forthcoming book that attempts to reorient this narrative.

Terrorism as a problem predates the 1980s, but the Reagan administration's approach differed from earlier ones because it used counterterrorism as a justification for making war on sovereign nations like Nicaragua. In the confusing and tumultuous $21^{\text {st }}$ century the terms 'terrorism' and 'war on terrorism' are often tossed around by the media and the political leadership in the United States, but few Americans really understand that these commonplace terms signify a landmark transformation in how the United States uses and justifies its use of force in the world. The basic definition of terrorism involves a range of violent actions perpetrated on non-combatants with the goal of achieving some kind of political objective. Acts of terrorism are carried out by non-state agents, terrorist organizations, and are often facilitated directly by state sponsors of terrorism. Likewise, a war on terror occurs anytime a government, in this case the United States, uses counterterrorism as a primary justification for taking aggressive actions to combat a terrorist threat from or within another nation. These seem like fairly simple concepts, however, let us look a little deeper. 


\section{Journal of Terrorism Research}

The standard definition of terrorism is primarily concerned with only the act of targeting innocents. From this standpoint, any side in a conflict regardless of affiliation or ideology might be guilty of conducting acts of terrorism. In the 1980s, many Americans understood this and accurately highlighted both rightist and leftist forms of terrorism in the bloody Central American wars that raged in places like El Salvador, Guatemala, and across the borders of Nicaragua. However, the Reagan administration, ultimately, decided to define the threat of terrorism as uniquely leftist and used it as a vehicle for the pursuit of its policy objectives within the Cold War.

During 1983, administration officials observed an unprecedented escalation of terrorist violence in Latin America. Of the 170 attacks against U.S. citizens and property that year, Latin America led all regions with nearly 80 incidents. Likewise, by 1985 Latin America made up 15.2 percent of all international terrorism in the globe, this was the third highest percentage following the Middle East and Western Europe. More importantly, just short of 50 percent of all international terrorist attacks on U.S. citizens and property occurred in Latin America. The period was plagued by a terrorism crisis. [7] The situation in the mid-1980s was so dire that former Deputy Director for Counterterrorism Parker Borg recalled, "There seemed to be hijackings or terrorist incidents almost continuously." [8]

Following the surge in terrorism the State Department began a process of redefining terrorism. Through this process it enlarged the catalogue of actions considered terrorist in nature, and limited the scope of legitimate insurgency. According to the State Department, a legitimate insurgency involved a group in which, "Its members wear a uniform [and] operates in the open." Further, "Its (insurgency) methods are military [and] its targets are military, both tactical and strategic, and its legitimate operations are governed by the international rules of armed conflict." Lastly, for the United States to recognize a revolutionary or guerrilla movement as a legitimate insurgency rather than a terrorist threat, "Its primary interests [must] relate to one country." [9] Effectively, no insurgency at any time previous or since fell into the administration's new definition. As an almost universal rule of insurgency combatants did not wear uniforms, operated as guerrillas, acted across national borders, possessed transnational links, and engaged in a wide array of violence. The United States moved to effectively consider any insurgency against its allies or interests as terrorist in nature, and thereby illegitimate.

As a result of this change the United States defined the Farabundo Martí National Liberation Front (FMLN), which led a revolution against the United States supported government in El Salvador, as a terrorist army with a membership numbering 7,500. The FMLN was a revolutionary insurgency, but this redefining placed it among the largest terrorist groups in the world. The Reagan administration catalogued and discussed the FMLN at length in Terrorist Group Profiles, a publication, for which, Vice President George H. W. Bush provided an eloquent introduction. Of course, Nicaragua and Cuba the administration deemed as the primary state sponsors of the FMLN.[10] The Reagan administration expanded the definition of terrorism to justify aggressive actions against insurgent groups and nations at odds with the United States by rebranding these groups as terrorist and illegitimate.

The Reagan administration's struggle with Sandinista-led Nicaragua went back to 1981. Its attempt to destabilize the Nicaraguan government by supporting clandestine guerrilla operations, however, was contentious and the administration met substantial resistance from Congress. Over time, however, the terrorism crisis of the mid-1980s allowed for a re-definition of the Nicaraguan conflict as not only a fight against communism, but also as a struggle in a new global war on terrorism. A critical component to the development of the Reagan administration's counterterrorism strategy involved the reconstruction of 


\section{Journal of Terrorism Research}

the meaning of terrorism in such a way that the language applied to not only criminal agents, but also to a wide array of revolutionary and political actors that opposed the United States. Over time, the Reagan administration included those initially considered outside the bounds of international terrorism as part of a broad and radical terrorist threat. These included communist-Marxist governments and insurgencies, leftist political activists, and drug traffickers. This effort to broaden the scope of terrorist groups and states continued into Reagan's second term as the administration sought to use such allegations as a motive for increased military pressure on Nicaragua.

Following the shocking events in El Salvador and Lebanon in June 1985, the Reagan administration announced publically that it was getting tough on terrorism. Speaking before the American Bar Association (ABA) on July 8, Reagan affirmed that the Executive Branch planned significant policy changes following the terrorist incidents. Reagan labeled five states as part of "a confederation of terror states" and a "new version of murder inc." that had attacked the United States and its allies with "outright acts of war." He listed Nicaragua, Cuba, Libya, Iran, and North Korea as the heart of world terrorism. In his own version of "the axis of evil" these states, he argued, were "outlaw states." The President acknowledged that the Cold War had changed, and that radical leftist regimes sought to use terrorism against the United States' allies and interests. Reagan announced his order to form a task force to evaluate and redevelop U.S. counterterrorism policy.[11]

On September 18, the heads of all pertinent agencies and departments met for the first time and provided direct insight to the task force on the course of U.S. terrorism policy. Vice President Bush opened the meeting and made key points about how the task force should define terrorism and what this meant to U.S. policy. In his opening remarks, he insisted, "Once the President approves the recommendations of this task force this congressional support affords a real opportunity to package legislation under anti-terrorism that will stand a good chance of passage." Bush implied that this new threat introduced a tool that could allow for the authorization from Congress of a more aggressive foreign policy in the name of counterterrorism.[12] According to the members present, the international character of the terror crisis and its role in a global anti-American offensive made it unique. The acts involved state supported transnational criminal agents. These individuals targeted citizens, soldiers, and world leaders through a network of loosely connected state sponsors. The leadership at the meeting perceived the threat primarily as a broad leftist offensive against the United States and, for this reason, Secretary of State George Shultz joined Bush in pressing for a definition of terrorism that facilitated the goals of the Reagan doctrine in places like Nicaragua. First, he insisted, "The international aspect of terrorism is the essence of the matter...the terrorist connections are international." Next, Shultz supported broadening the dimensions of what the United States regarded as international terrorism by incorporating the illegal drug trade into the catalogue of international terrorism. The allegation of Sandinista involvement in drug trafficking, so-called "narco-terrorism," enhanced the administration's call for military escalation. Shultz argued, "There is a definite connection with illicit drugs as a source of financing activities." A key component to the inclusion of Nicaragua in this war on terrorism related to the manner in which the United States defined the threat. The decision by the task force to define the problem broadly provided a justification for escalation against the Sandinistas.[13]

During the meeting some seemed to question whether actions against or within sovereign states might violate norms of international law. This issue pertained to applications of force against sovereign states not technically at war with the United States.[14] In response to this, Shultz implied that international law should not impede the United States' attempt to fight terrorism. He insisted, "We often torture ourselves with these moral dilemmas of justice when we forget the victims and the consequences of the incident." [15] The 


\section{Journal of Terrorism Research}

Secretary apparently believed that the United States needed to respond aggressively and if necessary without the impediment of "moral dilemmas of justice." [16] It was clear from this meeting that unilateral military action, aid to transnational guerrilla forces, and other preventative and pre-emptive measures were on the table as potentially acceptable options for dealing with 'outlaw states'.

Over the course of the next year George Shultz and George H. W. Bush led the way in explaining the new aggressive, unilateral, and pre-emptive approach that the United States adopted in 1985-1986. In May 1986, American Legion published an interview with the Vice President titled, "A Warning to Terrorists: We Will Protect Our Citizens." In the interview Bush insisted that Nicaragua was, contrary to popular opinion, a serious terrorist threat. Bush insisted, "While we usually associate terrorism with the Middle East, a very serious problem exists much closer to our borders. More terrorist acts were directed at U.S. citizens in Latin America last year than any other region. Both Nicaragua and Cuba have been implicated in this activity. Our support for the Contra cause against the Sandinistas is, in part, to ensure that we are not going to have a terrorist beachhead right in our own hemisphere." George H. W. Bush led the way in advocating an aggressive pre-emptive counterterrorist campaign against Sandinista-led Nicaragua. In Central America, the United States justified its support of the Contras as part of the fight against state sponsors of terrorism.[17]

The proposal of the task force was due by December 20,1985, and formally outlined the Reagan administration's counterterrorism policy. George H. W. Bush insisted that once signed the document represented "the gospel" for the future of U.S. counterterrorism policy.[18] Despite these bold assertions controversy reigned within the task force. Ambassador at Large for Counterterrorism, Robert Oakley, sent a critical letter to Executive Director of the task force retired Admiral James Holloway. Oakley was the head of the Office of Counterterrorism, located in the State Department. During 1985, Oakley gave numerous speeches on the emergent issue of international terrorism.[19] He understood the seriousness of the international terrorism problem. However, he disputed the role of military force as the primary method of combatting terror. By contrast, Oakley believed in a multilateral diplomatic approach that the United States could undertake without panicking the public, and which discriminated strictly between insurgencies and terrorists. He acknowledged the potential role of the military in counterterrorism strategy, but his own understanding, as a diplomat, was that the role of the military was for use as a last resort. While Oakley praised the overall process and the move to get serious on the issue of terrorism, his three-page letter to the task force was a stinging critique of the final report.[20]

On December 10, the Deputy Director for Counterterrorism, Parker Borg, also assailed the proposal. Borg was a diplomat well known for his service in Southeast Asia during the end of the Vietnam War and to African nations Zaire and Mali. Like Oakley, Borg preferred to approach the terrorism problem with nonmilitary means.[21] In 2002, he explained that both he and Oakley disagreed with the majority opinion in the task force on several key points. Specifically, the two disagreed with a broad definition of terrorism. Parker Borg insisted there was a difference between terrorism and the actions brought on by revolutionary warfare. For this reason, he recalled that the Office of Counterterrorism "declined...to consider the various groups in Central America, the Sandinistas or El Salvador groups... as being terrorists per-se." [22] The Office of Counterterrorism resisted the State Department's efforts to lump revolutionary factions in as part of the terrorism problem. Borg and Oakley offered a more specific and nuanced definition. This outlook, however, ran counter to the attempts of the task force, and most significantly of Shultz and Bush, to use terrorism as a way of carrying out the Reagan doctrine in Central America.

Despite the criticism from Robert Oakley and Parker Borg, the task force's final report went ahead as 


\section{Journal of Terrorism Research}

scheduled. Statements made by Bush, Shultz, and Reagan suggested that the majority in the National Security Council, the State Department, and the task force believed that the United States should escalate military operations against states like Nicaragua. On December 20,1985, the task force's recommendations went to President Reagan. One month later, Reagan signed "National Security Decision Directive Number 207: The National Program for Combatting Terrorism" (NSDD 207) and made the report of the task force official policy. The administration implemented the new policy in the following months.[23]

In addition to economic sanctions, the framework that the task force developed centered on several military options. These included support for insurgents, unilateral military strikes, clandestine operations of sabotage and assassination, and military and naval maneuvers designed to threaten, provoke, and/or act as a cloak for other military operations.[24] The administration re-affirmed a "no-concessions policy." [25] This meant that the United States refused to negotiate with terrorists and state sponsors, and that the alleged illegitimacy of states like Nicaragua meant that the United States refused to conduct fair negotiations. Instead, the administration promoted a military oriented policy that guaranteed an escalation of the conflict as a means to a U.S.-centric peace and democratization. The directive insisted, "The U.S. government considers the practice of terrorism.... a threat to our national security... and is prepared to act in concert with other nations or unilaterally when necessary to prevent or respond to terrorist acts." [26] Further, the document pledged, "States that practice terrorism or actively support it, will not be allowed to do so without consequence."[27] To deal with this threat it asserted, "The entire range of diplomatic, economic, legal, military, paramilitary, covert action and informational assets at our disposal must be brought to bear against terrorism." [28] In order to deter and defeat state sponsors the Reagan administration asserted a hardline that included restrictive economic measures, and an entire range of military options.

At the beginning of March 1986, the administration took steps to implement the offensive war on terrorism called for by the task force. On March 5, Deputy Secretary of Defense John Whitehead sent a message to the British at the U.S.-UK Bilateral Meeting on Terrorism that confirmed that the United States was adopting an offensive strategy. The confidential statement emphasized a shift in U.S. policy on the issue of terrorism and the Cold War. He asserted that the "USG [U.S. government] has concluded that the past approach has not yielded adequate results, [and we] must move to [a] more active, offensive policy." The statement continued, "Numbers and casualties of international terrorism demonstrate who is winning despite our intensified, defensive, containment approach." The administration made the decision, and this message was a notification to the United States' closest ally of the change.[29]

Nicaragua was at the center of the administration's new policy. On March 6, Vice President George H. W. Bush and Admiral James Holloway acknowledged in a public statement that the new counterterrorism approach targeted Nicaragua. On March 6, Bush and Holloway held a press conference and announced the release of the public version of the report of the task force.[30] Of all the countries and regions that the task force considered at risk or involved with international terrorism, the two emphasized Nicaragua. Speaking alongside Vice President Bush, Admiral Holloway insisted that, "More terrorist acts were directed at U.S. citizens in Latin America last year than in any other region. Both Nicaragua and Cuba have been implicated in terrorist activity in Latin America." [31] No other states were mentioned in this press conference, which announced the administration's new counterterrorism policy. The White House directed its war on terrorism against Nicaragua. Of all the possible targets for the new offensive, Nicaragua was primary.

In 1986, the administration applied the new framework of intervention offered by the task force in an escalated effort to place increased military pressure on the government of Nicaragua. This involved 


\section{Journal of Terrorism Research}

threatening U.S.-Honduran military maneuvers on Nicaragua's border coupled with increased clandestine support for the Contras. The result was a major escalation. The Sandinista army launched a responsive invasion into border areas of Honduras, and the Reagan administration publicized the event and used it to build support in the United States Congress for the Contras. By the end of the summer Congress approved, for the first time, lethal support to the Nicaraguan Contras and effectively authorized the Reagan administration's policy of regime change in Nicaragua. Of course, the revelations surrounding the IranContra affair, which emerged in the fall of 1986, derailed this effort shortly after it began.[32]

The Nicaraguan policy was not an anomaly, but rather a product of the Reagan administration's global war on terrorism. At the same time that the United States targeted Nicaragua it also targeted another nation deemed a sponsor of terrorism, and an ally of the Sandinistas. The country was Libya. Simultaneous to the Honduran operations the United States applied a similar approach against Libya beginning with provocative naval maneuvers that incited a direct engagement and was used to build support in Congress and with the public for the administration's more aggressive posture. In a memo to Reagan, National Security Advisor John Poindexter praised the actions as, "Unilateral military action [that] decreased terrorism at the source by putting state sponsors on notice." [33] Together the actions against Nicaragua and Libya represented a broad reaching war on terrorism conducted by the Reagan administration.

Long before George W. Bush's invasions of Iraq and Afghanistan, the Reagan administration constructed its own counterterror offensive. In the middle of the 1980s, the Reagan administration reacted to violence in the Middle East and Latin America. In its response, it redesigned U.S. counterterrorism strategy by broadly defining the terrorism threat and using it to justify the use of military pressure against Nicaragua and other radical powers. In 1986, the administration targeted both Nicaragua and Libya. In Central America, the approach hinged on taking steps to isolate and escalate hostilities with Nicaragua in pursuit of the forceful alteration of the government of Nicaragua. Terrorism provided a tool for justifying a policy of pre-emptive regime change.

In its own war on terrorism the Reagan administration defined and applied the allegation of terrorism one-sidedly. It associated the term almost universally with leftism and toward its enemies. Simultaneous to waging a war on terrorism the Reagan administration supported groups that clearly perpetrated acts of terror. In Central America, the United States supported and supplied a transnational guerrilla army, the Contras. The administration defined these fighters as "freedom fighters" and even insisted that its leaders resembled the founders of the United States. However, journalists, activist, and the International Court of Justice demonstrated that these guerrillas acted in violation of international law and of the sovereign rights of Honduras, Costa Rica, and Nicaragua. The Contras killed civilians and according to an investigative committee headed by Senator John Kerry were intertwined in drug trafficking to the United States.[34] In short, the Contras fit the administration's own loose definition as terrorists. The Reagan administration, however, consistently ignored acts of terrorism perpetrated by its allies. Instead, it hid an aggressive Cold War realism and policy of regime change in the cloak of human rights and counterterrorism. Terrorism for the United States had more to do with which side of the geo-political spectrum a state or group was affiliated. Terrorism was a way of justifying aggression against Cold War enemies.

Not only did the United States support proxy armies that conducted acts of terrorism, the Reagan administration also facilitated state terrorism in the civil wars in both Guatemala and El Salvador. In Empires Workshop and The Last Colonial Massacre historian Greg Grandin demonstrated that the United States used the Central American conflicts to implement a policy of state terrorism that involved targeting civilians 


\section{Journal of Terrorism Research}

with sabotage, assassination, and forcible relocation as a way of combatting insurgencies that threatened the influence and control of the United States in its most intimate imperial domain, Central America. Its support of such policies undermined democratic movements, enfranchised the elite in Central America, and caused the destruction of the lives of thousands of people. While the United States attacked its enemies and justified a policy of regime change with allegations of state sponsorship of terrorism, it actively supported militants and governments that utilized violence against civilians as a fundamental component of its Central American policy.[35]

In order to defend its policy of regime change in Nicaragua the Reagan administration peppered the American public with incessant allegations that the government of Nicaragua was a state sponsor of international terrorism. It was from this public defense that the Nicaraguan terrorist in the film Speedzone originated. Nicaragua was not openly complicit in major acts of terrorism during the 1980s, but the Reagan administration's continual assertion that its involvement in the war in El Salvador was tantamount to international terrorism reshaped the public image of Nicaragua. The Reagan administration's portrayal of the Sandinista terrorist came to life in the film Speedzone as well as other, more serious films, like the blockbuster smash hit Red Dawn.

Terrorism presented a real problem in the 1980s, but the United States provided a one sided portrayal of the problem as a way of justifying an aggressive policy of pre-emptive regime change. This policy lay at the heart of the Reagan offensive. Still today, the United States appears to rely on a one sided interpretation of the terrorism problem. The United States openly supports allies that conduct brutal public executions or launch military incursions that target opponents with little concern for the lives of innocents. Most recently, the United States armed militants dedicated to the overthrow of the sovereign and internationally recognized government of Syria. Apart from the goal of regime change these militants, in some cases, joined groups like the Islamic State, a problem that policy makers recognized as potential blowback from its support of Syrian militants. Perhaps more than at any time prior, the United States utilizes the allegation of terrorism as a justification for aggressive applications of power, but it consistently fails to acknowledge either its or its allies complicity in acts that observers may rightfully claim as terrorist in nature.

\section{About the author}

Philip Travis completed his Ph.D. from Washington State University in May, 2014. His research is focused on United States international relations during the Cold War until present. Travis is currently an Assistant Professor of History with the State College of Florida.

\section{Notes}

[1] Michael Short, Speed Zone, DVD, directed by Jim Drake, (1989: Orion)

[2] Dena Kleiman, “Those Still Captive: 40 Remaining Hostages: A Diverse Group United by the Random Nature of Their Plight Hostages in Lebanon: Who the Captives Are," New York Times, June 21, 1985, http:// search.proquest.com/docview/111148555?accountid=14902

[3] Shirley Christian, "Four Marines Slain in Rebel Raid in El Salvador," New York Times, June 21, 1985, http://search.proquest.com/docview/111140226? accountid=14902 


\section{Journal of Terrorism Research}

[4] Walter LaFeber, Inevitable Revolutions: The United States in Central America, $2^{\text {nd }}$ ed. (New York: W.W. Norton, 1993); Cynthia Arnson, Crossroads: Congress, the President, and Central America, 1976-1993 2 ed. (University Park: Penn St. University Press, 1993); William LeoGrande, Our Own Backyard: The United States in Central America, 1977-1992 (London: University of North Carolina Press, 1998); Grandin, Empires Workshop; Robert Kagan, A Twilight Struggle: American Power and Nicaragua, 1977-1990 (New York: The Free Press, 1996)

[5] Mahmood Mamdani, Good Muslim, Bad Muslim: America, the Cold War, and the Roots of Terror (New York: Double Day, 2004); Mahmood Mamdani, Saviors and Survivors: Darfur, Politics, and the War on Terror (New York: Double Day, 2009); Chalmers Johnson, Blowback: The Costs and Consequences of American Empire (New York: Henry Holt, 2004); Odd Arne Westad, The Global Cold War (New York: Cambridge University Press, 2007)

[6] David C. Wills, The First War on Terrorism: Counterterrorism Policy During the Reagan Administration (Oxford: Rowan and Littlefied, 2003), 10

[7] U.S. Department of State "Patterns of Global Terrorism: 1985," in Robert A. Friedlander, Terrorism: Documents of International and Local Control (New York: Oceania Press, 1990), 80-81

[8] Parker Borg, Interview by Charles Stuart Kennedy, Foreign Affairs Oral History Project, Association for Diplomatic Studies and Training, August 12, 2002

[9] Memo from McFarlane to Meese, "Background Material on Terrorism," August 15, 1984, The Digital National Security Archive (Proquest: Ann Arbor 2012), “Terrorism and U.S. Policy, 19682002," TE00715. http://gateway.proquest.com/openurl?url ver=Z39.88-2004\&res dat=xri:dnsa\&rft dat=xri:dnsa:article:CTE00715

[10] “Terrorist Group Profiles” Nov 1988, viii. The Digital National Security Archive (Ann Arbor: Proquest, 2012), TE00967. http://gateway.proquest.com/openurl?url ver=Z39.88 2004\&res_dat=xri:dnsa\&rft_ dat=xri:dnsa:article:CTE00967

[11] Bernard Weinraub, “President Accuses 5 'Outlaw States' of World Terror,” New York Times, July 9, 1985, http://search.proquest.com/docview/425474442?accountid=14902

[12] Memo, Admiral Holloway, Minutes of the Second Task Force meeting September 19 1985, folder “Second Meeting With Task Force Principles," Box 32, Oliver North Files, Ronald Reagan Presidential Library [13] Memo, Admiral Holloway, Minutes of the Second Task Force meeting September 19 1985, folder “Second Meeting With Task Force Principles," Box 32, Oliver North Files, Ronald Reagan Presidential Library [14] Issue Paper 2: National Policy for Combatting Terrorism, folder "Meeting with the Vice President and Selected Ambassadors 10/31/1985 - Folder 1 or 2" Box 32, Oliver North Files, Ronald Reagan Presidential Library

[15] Memo, Admiral Holloway, Minutes of the Second Task Force meeting September 19 1985, folder “Second Meeting With Task Force Principles," Box 32, Oliver North Files, Ronald Reagan Presidential Library [16] Memo, Admiral Holloway, Minutes of the Second Task Force meeting September 19 1985, folder "Second Meeting With Task Force Principles," Box 32, Oliver North Files, Ronald Reagan Presidential Library 
[17] Interview with George H. W. Bush, "A Warning to the Terrorists: We Will Protect Our Citizens," American Legion Magazine, May 21, 1986, Folder 3 of 3 OA/ID 19849, Donald, Gregg P. Files, subject files. George H. W. Bush Vice Presidential Records, National Security Affairs, Office Of, Holloway's Terrorism Review. OA/ID 19863-010

[18] Oakley to Holloway, December 6, 1985, folder “Incoming 12/6/1985," Box 32/34, Oliver North Files, Ronald Reagan Presidential Library

[19] Oakley Speaking before the Committees on Senate Foreign Relations and Judiciary, May 15, 1985, "International Terrorism, Current Trends and the U.S. Response," Folder "Combatting Terrorism Department of State Report, 19851 of 2," Box 1 OA/ID CF01573, Richard L. Canas, Files: National Security Council, George Bush Presidential Library

[20] Oakley to Holloway, December 6, 1985, folder “Incoming 12/6/1985," Box 32/34, Oliver North Files, Ronald Reagan Presidential Library

[21] Memorandum, Parker Borg to the Task Force, December 10, 1985, folder "NSDD 207 NSC Staff: Craig Coy; Robert Earl, Folder 6 of 7," Box 91956, No. 2, Counterterrorism and Narcotics Directorate NSC Records, NSC Office of, Ronald Reagan Presidential Library

[22] Parker Borg, Interview by Charles Stuart Kennedy, Foreign Affairs Oral History Project, Association for Diplomatic Studies and Training, August 12, 2002

[23] NSDD 207, January 20, 1986, folder, “Counterterrorism (8/8/1985-4/10/1986) Vincent Cannistraro: Files, Series 2, Box 2, Ronald Reagan Presidential Library

[24] "Policy Framework for the Use of Force in Response to Terrorist Incidents," folder, "Program Review of the Vice President's Task Force on Combatting Terrorism - March-April 1987," Box 1, Carolyn Stettner: Subject Files OA/ID CF01523-004, George Bush Presidential Library

[25] NSDD 207, January 20, 1986, folder, “Counterterrorism (8/8/1985-4/10/1986) Vincent Cannistraro: Files, Series 2, Box 2, Ronald Reagan Presidential Library

[26] NSDD 207, January 20, 1986, folder, “Counterterrorism (8/8/1985-4/10/1986) Vincent Cannistraro: Files, Series 2, Box 2, Ronald Reagan Presidential Library

[27] NSDD 207, January 20, 1986, folder, “Counterterrorism (8/8/1985-4/10/1986) Vincent Cannistraro: Files, Series 2, Box 2, Ronald Reagan Presidential Library

[28] NSDD 207, January 20, 1986, folder, “Counterterrorism (8/8/1985-4/10/1986) Vincent Cannistraro: Files, Series 2, Box 2, Ronald Reagan Presidential Library

[29] Statement By Deputy Director Whitehead at “US-UK Bilateral Meeting on Terrorism," March 5, 1986, Folder, “Terrorism (folder 1)," Box 2, Vincent Canistraro: Files, Series 2, Ronald Reagan Presidential Library [30] “Public Report of the Vice President's Task Force on Combatting Terrorism, February 1986," Folder, "Public Report of the Vice President's Task Force on Combatting Terrorism, February 1986," OA 18547, Box 1, Roman Popadiuk: Files, Ronald Reagan Presidential Library

[31] George Bush, summation of the findings of the terrorism task force, February 1986, Folder, “Terrorism - II: Terrorism Article (2 of 3)” OA/ID 19849 Box 1, Donald Gregg: Task Force on Terrorism Files, George Bush Presidential Library 


\section{Journal of Terrorism Research}

[32] James Lemoyne, “Honduran Tells of U.S. Pressure," New York Times, April 3, 1986, http://search. proquest.com/docview/110973739? accountid $=45760$

[33] Memo, Poindexter to President Reagan, “Implementation of NSDD 207” folder, “folder 3," Box 91956, Counterterrorism and Narcotics: NSC Office Records, Ronald Reagan Presidential Library

[34] "Drugs, Law Enforcement, and Foreign Policy: A Report Prepared by the Subcommittee on Terrorism, Narcotics, and International Operations," (U.S. Government Printing Office: Washington D. C. 1989)

[35] Greg Grandin, Empires Workshop: Latin America, The United States, And the Rise of the New Imperialism (New York: Henry Holt, 2006); Greg Grandin, The Last Colonial Massacre: Latin America in the Cold War (Chicago: University of Chicago, 2004) 